\title{
Pengaruh Paparan Medan Magnet 0,2 mT Pada Ion Logam Fe dan Zn Dalam Media Pertumbuhan Terhadap Produksi Protease Bacillus sp
}

\author{
Sumardi*, Rochmah Agustrina, Bambang Irawan, dan Indah Selfiana \\ Jurusan Biologi, FMIPA Universitas Lampung Jl. Sumantri Brojonegoro No. 1 Gedong Meneng Bandar Lampung \\ *Corresponding author: sumardi_bio@yahoo.co.id
}

\begin{abstract}
ABSTRAK
Tujuan penelitian ini adalah mengetahui pengaruh paparan medan magnet $0.2 \mathrm{mT}$ pada ion logam Fe dan $\mathrm{Zn}$ dalam media pertumbuhan terhadap produksi protease Bacillus sp. Ion logam yang digunakan yaitu Fe dan $\mathrm{Zn}$ dalam bentuk garam $\mathrm{FeCl}_{3}$ dan $\mathrm{ZnCl}_{2}$. Hasil penelitian menunjukkan bahwa ion logam $\mathrm{Fe}(0.01 \% \mathrm{~b} / \mathrm{v})$ yang terpapar medan magnet mempunyai nilai Indeks Proteolitik 3,36 dengan lama inkubasi 10 jam, dan indeks proteolitik 2,74 dengan lama inkubasi $18 \mathrm{jam}$. Sedang ion logam Fe $(0.01 \% \mathrm{~b} / \mathrm{v})$ yang tidak terpapar medan magnet mempunyai nilai Indeks Proteolitik 1,79 dengan lama inkubasi 10 jam, dan indeks proteolitik 2,12 dengan lama inkubasi 18 jam. Sedangkan pada ion logam $\mathrm{Zn}(0.005 \% \mathrm{~b} / \mathrm{v})$ yang terpapar medan magnet dan tidak terpapar medan magnet menyebabkan aktivitas Bacillus mati. Larutan ion logam Fe $0,01 \%$ dalam media cair menghasilkan produksi protease lebih baik $(0,06$ $\mathrm{U} / \mathrm{ml})$ dibandingkan dengan produksi protease tanpa dipemapar medan magnet $(0,00 \mathrm{U} / \mathrm{ml})$.
\end{abstract}

Kata kunci: Bacillus sp., paparan medan magnet, indeks proteolitik.

\begin{abstract}
The purpose of this study was to determine the effect of metal ions Fe and $\mathrm{Zn}$ were exposed to a magnetic field of 0.2 $\mathrm{mT}$ to the production of proteases in Bacillus sp. The metal ions used are Fe and $\mathrm{Zn}$ in the form of $\mathrm{FeCl}_{3}$ and $\mathrm{ZnCl}_{2} \mathrm{salts}_{\text {. }}$ The results showed that the culture medium containing metal ions $\mathrm{Fe}(\mathrm{a} 0.01 \% \mathrm{w} / \mathrm{v})$ were exposed by the magnetic field has a value of proteolytic index of 3.36 with 10 hour long incubation, and proteolysis index of 2.74 with 18 hour incubation time. Culture medium containing metal ions $\mathrm{Fe}(\mathrm{a} 0.01 \% \mathrm{w} / \mathrm{v})$ which are not being exposed to the magnetic field has a value of proteolytic index of 1.79 with 10-hour long incubation, and proteolysis index of 2.12 with 18 hour incubation time. While the culture medium containing metal ions $\mathrm{Zn}(0.005 \% \mathrm{w} / \mathrm{v})$ either exposed or not exposed to the magnetic field causes the activity of Bacillus sp die. The solution of $0.01 \%$ Fe metal ion in liquid medium resulted in better protease production $(0.06 \mathrm{U} / \mathrm{ml})$ than production of proteases without exposure to magnetic fields $(0.00$ $\mathrm{U} / \mathrm{ml}$ )
\end{abstract}

Keywords: Bacillus sp., magnetic field, proteolytic index, and proteolysis index

Sitasi: Sumardi, Agustrina R., Irawan B., dan I. Selfiana. (2018). Pengaruh Paparan Medan Magnet 0,2 mT pada Ion Logam Fe dan Zn dalam media pertumbuhan terhadap produksi Protease Bacillus sp. Jurnal Ilmu Lingkungan, 16(2), 173177,doi:10.14710/jil.16.2.173-177

\section{Pendahuluan}

Salah satu faktor lingkungan, yakni medan magnet dapat mempengaruhi mikroba dalam menghasilkan enzim. Fe adalah senyawa ferromagnetik yang digunakan sebagai induktor (peningkatan efek kerja enzim yang lebih baik) pada pertumbuhan dan kemampuan Bacillus sp. dalam menghasilkan enzim protease sedangkan $\mathrm{Zn}$ adalah salah satu golongan logam transisi yang bersifat diamagnetik dapat berperan sebagai inhibitor protease.

Salah satu upaya untuk meningkatkan kemampuan Bacillus sp dalam memproduksi protease adalah dengan penambahan $\mathrm{Fe}$ dan $\mathrm{Zn}$ dalam mediumnya. Fe diperlukan untuk aktivitas metabolisme pada hampir semua mikroorganisme karena sebagai kofaktor untuk sejumlah enzim (He et al., 2011). Sedangkan Zn adalah salah satu golongan logam transisi yang dapat berperan sebagai inhibitor protease (Vidyasagar et al., 2006). Pengaruh medan magnet secara fisika terhadap kedua ion logam tersebut memberikan hasil yang berbeda.

Bahan paramagnetik termasuk Zn, apabila diberi medan magnet dari luar maka momen magnet yang awalnya acak akan menata diri sehingga menjadi searah medan magnet luar. Namun apabila magnet luar dihilangkan maka momen magnetnya kembali acak. Pada bahan feromagnetik termasuk Fe, saat medan magnet dihilangkan maka momen magnet tetap mampu mempertahankan diri searah medan magnet dari luar. 
Penelitian tentang peran medan magnet dalam bidang mikrobiologi saat ini mulai banyak dilakukan. Medan magnet dilaporkan dapat mempengaruhi aktivitas enzim peroxidase, catalase dan superoxide dismutase (Lie, 2015). Hasil penelitian yang dilakukan oleh Agustrina (2013) menyimpulkan bahwa kuat medan magnet $0.1 \mathrm{mT}$ dengan lama paparan 7'48', 11'44', dan 15'36" dapat meningkatkan aktivitas enzim $\alpha$-amilase pada kacang merah dan kacang buncis hitam (Phaseolus vulgaris L.). Sari dkk. (2011) dalam percobaannya juga menyatakan bahwa perendaman pada biji dan pemaparan medan magnet $0.2 \mathrm{mT}$ dapat meningkatkan ukuran sel parenkim, xylem, serta lebar stomata pada tanaman tomat.

Atas dasar berbagai hasil penelitian tersebut, maka perlu dilakukan penelitian untuk melihat pengaruh paparan medan magnet $0.2 \mathrm{mT}$ pada ion logam $\mathrm{Fe}$ dan $\mathrm{Zn}$ terhadap pertumbuhan dan kemampuan Bacillus sp dalam menghasilkan enzim protease. Ion logam yang digunakan yaitu Fe dan Zn dalam bentuk garam $\mathrm{FeCl} 3$ dan $\mathrm{ZnCl} 2$.

\section{Material dan Metode Penelitian}

\subsection{Materi Penelitian}

Kultur Bacillus sp diambil dari koleksi dari laboratorium Mikrobiologi FMIPA Universitas Lampung. Bakteri penghasil protease tersebut diisolasi dari usus ayam kampung.

Sedang media percobaan menggunakan media modifikasi Mendels dengan komposisi terdiri dari susu skim; 0,5 g; Yeast Extract 0,35 g; Triptone Water $0,35 \mathrm{~g} ; \mathrm{NaCl} \mathrm{0,2}$ g; KH2PO4 0,245 g; MgSO4.7H2O 0,035 g; (NH4)2SO4 0,175 g dalam $100 \mathrm{~mL}$ aquades serta 1,5 g agar sebagai pemadat.

\subsection{Penentuan Indeks Proteolitik (IP)}

Indeks Proteolitik (IP) merupakan ukuran yang menunjukkan nisbah antara diameter zona jernih terhadap diameter koloni (Durham et al., 1987). Nilai IP isolat $\geq 3$ menunjukkan bahwa isolat memiliki potensi besar dan maksimal sebagai sumber protease (Said dkk., 2012). Indeks proteolitik dapat dihitung menggunakan rumus:

$$
\mathrm{IP}=\frac{\mathrm{B}}{\mathrm{A}}
$$

Ket:

IP : Indeks Proteolitik

A : Diameter koloni

B : Diameter Zona jernih (Sumardi dkk., 2010).

Bacillus sp ditumbuhan pada media padat dengan 6 perlakuan sebagai berikut:

- Perlakuan $1\left(\mathrm{M}_{0} \mathrm{~L}_{0}\right)$. Perlakuan $\mathrm{M}_{0} \mathrm{~L}_{0}$ merupakan perlakuan kontrol dimana media padat yang tidak diberi paparan medan magnet dan tidak diberi induktor.

- Perlakuan $2\left(\mathrm{M}_{1} \mathrm{~L}_{0}\right)$. Perlakuan $\mathrm{M}_{1} \mathrm{~L}_{0}$ adalah perlakuan dengan menggunakan media padat yang dipapar medan magnet $0.2 \mathrm{mT}$ selama 10 menit tetapi tanpa diberi induktor.

- Perlakuan $3\left(\mathrm{M}_{0} \mathrm{~L}_{1}\right)$. Perlakuan $\mathrm{M}_{0} \mathrm{~L}_{1}$ adalah perlakuan yang diberi induktor $\mathrm{FeCl}_{3}$ dengan konsentrasi $0.01 \%$. Baik media maupun induktor tidak dipapar medan magnet.

- Perlakuan $4\left(\mathrm{M}_{1} \mathrm{~L}_{1}\right)$. Perlakuan $\mathrm{M}_{1} \mathrm{~L}_{1}$ adalah perlakuan yang diberi diberi induktor $\mathrm{FeCl}_{3}$ dengan konsentrasi $0.01 \% . \mathrm{FeCl}_{3}$ dipapar medan magnet $0.2 \mathrm{mT}$ selama 10 menit.

- Perlakuan $5\left(\mathrm{M}_{0} \mathrm{~L}_{2}\right)$. Perlakuan $\mathrm{M}_{0} \mathrm{~L}_{2}$ adalah perlakuan yang diberi induktor $\mathrm{ZnCl}_{2}$ dengan konsentrasi $0.005 \%$. Baik media maupun induktor tidak dipapar medan magnet.

- Perlakuan $6\left(\mathrm{M}_{1} \mathrm{~L}_{2}\right)$. Perlakuan $\mathrm{M}_{1} \mathrm{~L}_{2}$ adalah perlakuan diberi induktor $\mathrm{ZnCl}_{2}$ dengan konsentrasi $0.005 \% . \quad \mathrm{ZnCl}_{2}$ dipapar medan magnet $0.2 \mathrm{mT}$ selama 10 menit.

\subsection{Produksi Enzim Protease pada Media Cair}

Produksi enzim protease dilakukan dengan menginokulasikan $5 \mathrm{ml}$ starter Bacillus sp pada $45 \mathrm{ml}$ media cair Mendels yang dimodifikasi dengan perlakuan sama untuk media padat. Namun perlakuan 5 dan 6 tidak dilakukan karena bakteri Bacillus sp tidak tumbuh pada media padat yang mengandung $\mathrm{ZnCl}_{2}$. Semua perlakuan kultur diinkubasi dalam inkubator goyang dengan kecepatan 120 rpm pada suhu $40^{\circ} \mathrm{C}$ dengan lama waktu inkubasi 18 jam yang disesuaikan dengan penelitian sebelumnya. Selanjutnya ekstraksi enzim protease dilakukan dengan cara sentrifugasi media pertumbuhan bakteri dengan kecepatan $3000 \mathrm{rpm}$ selama 15 menit pada suhu $4^{\circ} \mathrm{C}$. Supernatan diambil sebagai sampel uji aktivitas enzim protease (Yusufa dkk., 2013).

\subsection{Uji Aktivitas Protease}

Aktivitas protease diuji dengan mengukur kadar asam amino sebagai produk hidrolisis protein susu skim oleh enzim protease (Soeka dan Sulistiyani, 2014).

Sebanyak $0.2 \mathrm{ml}$ protease ditambahkan pada campuran yang berisi $1 \mathrm{ml}$ substrat kasein dalam buffer fosfat $0.01 \mathrm{M} \mathrm{pH} 7$ dan diinkubasi pada suhu $37^{\circ} \mathrm{C}$ selama 10 menit. Setelah itu ditambah $1 \mathrm{ml}$ TCA $0.1 \mathrm{M}$ kemudian diinkubasi pada suhu $37^{\circ} \mathrm{C}$ selama 10 menit, dan disentrifugasi dengan kecepatan $4000 \mathrm{rpm}$ pada suhu $4^{\circ} \mathrm{C}$ selama 10 menit. Kemudian diambil $0.75 \mathrm{ml}$ supernatan dan ditambah dengan $2.5 \mathrm{ml}$ larutan $\mathrm{Na}_{2} \mathrm{CO}_{3} \quad 0.4 \mathrm{M}$ dan $0.5 \mathrm{ml}$ pereaksi Folin, diinkubasi pada suhu $37^{\circ} \mathrm{C}$ selama 20 menit dan diukur absorbansinya pada panjang gelombang 578 nm (Bergmeyer dan Grassl, 1983). 
Sumardi, Agustrina R., Irawan B., dan I. Selfiana. (2018). Pengaruh Paparan Medan Magnet 0,2 mT pada Ion Logam Fe dan Zn dalam media pertumbuhan terhadap produksi Protease Bacillus sp. Jurnal Ilmu Lingkungan, 16(2), 173-177,doi:10.14710/jil.16.2.173-177

\section{Hasil dan Pembahasan}

\subsection{Bakteri Bacillus sp. Penghasil Enzim Protease}

Aktivitas proteolitik Bacillus sp. pada media padat terlihat adanya pembentukkan zona jernih di sekitar koloni bakteri yang tumbuh. Media seleksi yang digunakan dalam penelitian ini mengandung susu sebagai substrat. Susu mengandung kasein yang sesuai untuk pertumbuhan bakteri proteolitik (Zahidah dan Shovitri, 2013). Dengan dihasilkannya enzim protease oleh Bacillus sp. kasein ini akan terhidrolisis menjadi peptida-peptida kecil dan asam amino yang ditandai dengan terbentuknya zona jernih disekitar koloni. Semakin luas zona jernih yang terbentuk menunjukkan bahwa bakteri tersebut memiliki kemampuan yang tinggi dalam mengubah substrat yang terkandung dalam medium pertumbuhan (Vijayaraghavan et al., 2013).

\subsection{Nilai Indeks Proteolitik (IP)}

Selain dilihat dari ada atau tidaknya zona jernih, kemampuan proteolitik Bacillus sp dapat dilihat dari nilai indeks proteolitik (IP). Adapun hasil perhitungan Indeks Proteolitik (IP) Bacillus sp. dari enam perlakuan disajikan pada tabel berikut.

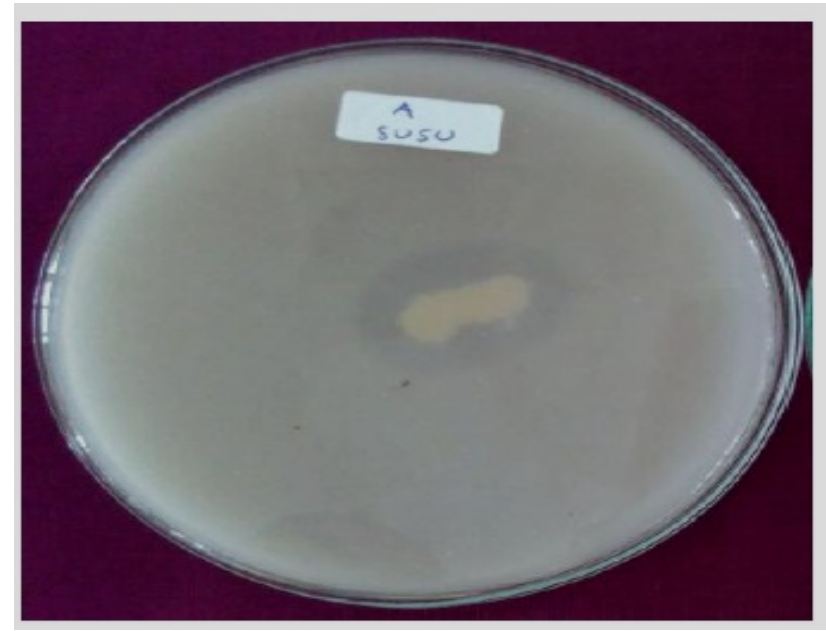

Gambar 1. Zona jernih yang terbentuk di sekitar koloni bakteri

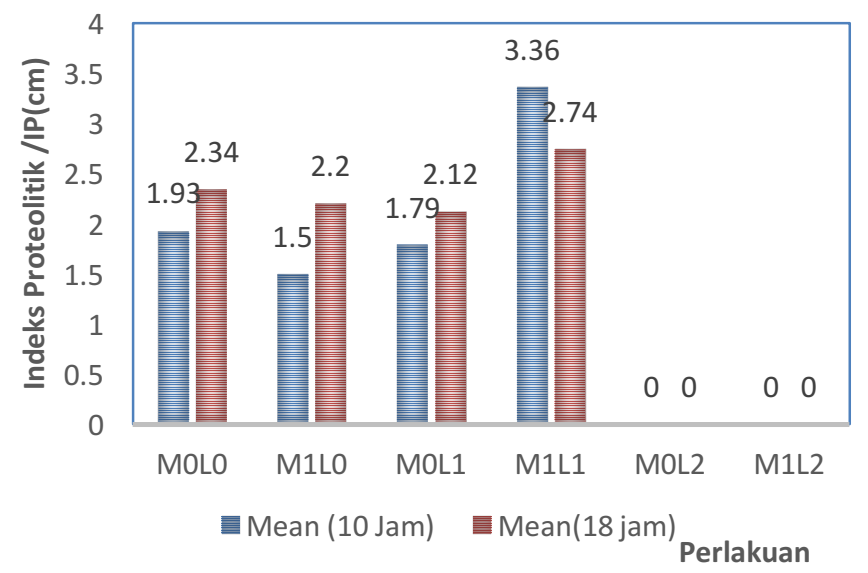

Gambar 2. Nilai Indeks Proteolitik Bacillus sp. pada media padat.

Keterangan : $\quad \mathrm{M}_{0} \mathrm{~L}_{0}$ : media kontrol (tanpa induktor Fe dan $\mathrm{Zn}$ ),

$\mathrm{M}_{1} \mathrm{~L}_{0}$ : media kontrol, dipapar medan magnet (tanpa induktor Fe dan Zn)

$\mathrm{M}_{0} \mathrm{~L}_{1}$ : media dengan induktor $\mathrm{FeCl}_{3}$ tanpa dipapar medan magnet,

$\mathrm{M}_{1} \mathrm{~L}_{1}$ : media dengan induktor $\mathrm{FeCl}_{3}$ dipapar medan magnet,

$\mathrm{M}_{0} \mathrm{~L}_{2}$ : media dengan induktor $\mathrm{ZnCl}_{2}$ tanpa dipapar medan magnet,

$\mathrm{M}_{1} \mathrm{~L}_{2}$ : media dengan induktor $\mathrm{ZnCl}_{2}$ dipapar medan magnet.

Hasil perhitungan nilai indeks proteolitik (IP) dari enam perlakuan menunjukkan nilai indeks proteolitik yang berbeda-beda baik pada waktu inkubasi 10 jam maupun 18 jam. Hal ini disebabkan karena perbedaan perlakuan yang diberikan. Isolat pada perlakuan M1L1 yaitu bakteri ditumbuhkan pada media padat Mendels yang dimodifikasi dan diberi induktor $\mathrm{FeCl} 3$ dengan konsentrsi $0.01 \%$ yang telah dipapar medan magnet $0.2 \mathrm{mT}$ selama 10 menit memiliki nilai indeks proteolitik paling tinggi baik pada waktu inkubasi 10 jam maupun 18 jam yaitu berturut-turut 3.36 dan 2.74. Hal ini diduga karena adanya penambahan $\mathrm{FeCl} 3$ yang telah dipapar medan magnet maka sifat kemagnetan yang tersimpan pada media akan 
mempengaruhi pertumbuhan bakteri yang tumbuh pada media tersebut. Seperti yang dilaporkan oleh Sudarti dkk. (2014) bahwa medan magnet dapat berpengaruh langsung terhadap aktivitas metabolisme sel salah satunya dalam menghasilkan enzim. Momen magnet pada $\mathrm{FeCl} 3$ diduga membuat konformasi protease sedemikian rupa sehingga menginduksi enzim menjadi lebih mudah untuk menerima dan memotong protein susu.

Pada perlakuan M0L2 dan M1L2 tidak ada pertumbuhan bakteri. Ion logam yang terdapat dalam garam $\mathrm{ZnCl} 2$ dapat merusak permeabilitas membran sel bakteri yang menyebabkan pertumbuhan bakteri menjadi terhambat sehingga akan mempengaruhi produksi enzimnya (Trianie, 2014).

Pada perlakuan M1L2, ZnCl2 yang diberi paparan medan magnet $0.2 \mathrm{mT}$ selama 10 menit juga tidak memberikan pengaruh terhadap aktivitas Bacillus sp. Zn merupakan ion logam bersifat diamagnetik dimana setelah paparan medan magnet dari luar tersebut dihilangkan maka arah kemagnetan tidak beraturan lagi. Akibatnya pengaruh terhadap bakteri relatif sama seperti yang tidak diberi medan magnet, sehingga bakteri tidak dapat tumbuh.

\subsection{Produksi Enzim Protease pada Media Cair}

Dalam produksi enzim protease pada media cair, kondisi lingkungan akan memberikan kesempatan bagi sel bakteri untuk dapat memanfaatkan kegiatan metabolismenya secara maksimal. Sel bisa bergerak secara leluasa dalam menjangkau nutrisinya. Perlakuan 5 dan perlakuan 6 tidak dilakukan pada media cair karena pada media padat yang mengandung $\mathrm{ZnCl} 2$ tersebut tidak tumbuh.

Perlakuan 1 (M0L) dan perlakuan 4 (M1L1) menghasilkan aktivitas enzim protease secara nyata lebih tinggi dari dua perlakuan yang lain yaitu M1L0 dan M0L1. Sedangkan antara perlakuan M1L0 dan M0L1 menunjukkan tidak ada aktivitas enzim protease yang berbeda nyata (Gambar 4).

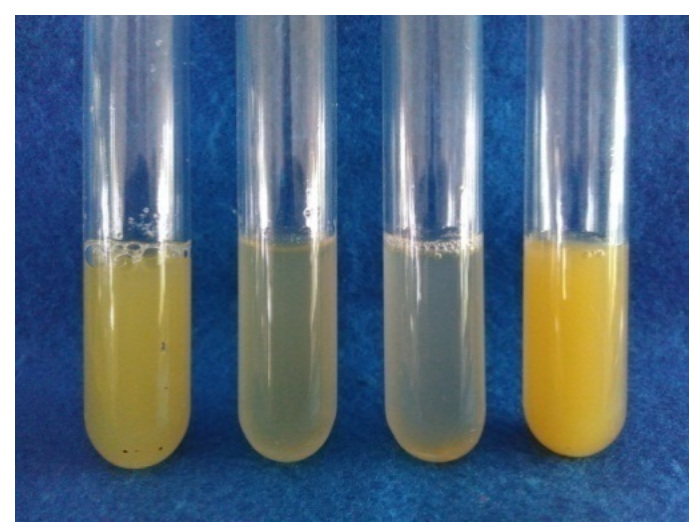

Gambar 3. Kultur protease dari Bacillus sp. pada media cair tanpa perlakuan medan magnet $\left(\mathrm{M}_{0}\right)$, yang diberi perlakuan medan magnet $0.2 \mathrm{mT}$ selama 10 menit $\left(\mathrm{M}_{1}\right)$, media padat tidak mengandung ion logam $\mathrm{Fe}\left(\mathrm{L}_{0}\right)$, media mengandung ion logam $\mathrm{Fe}\left(\mathrm{L}_{1}\right)$.

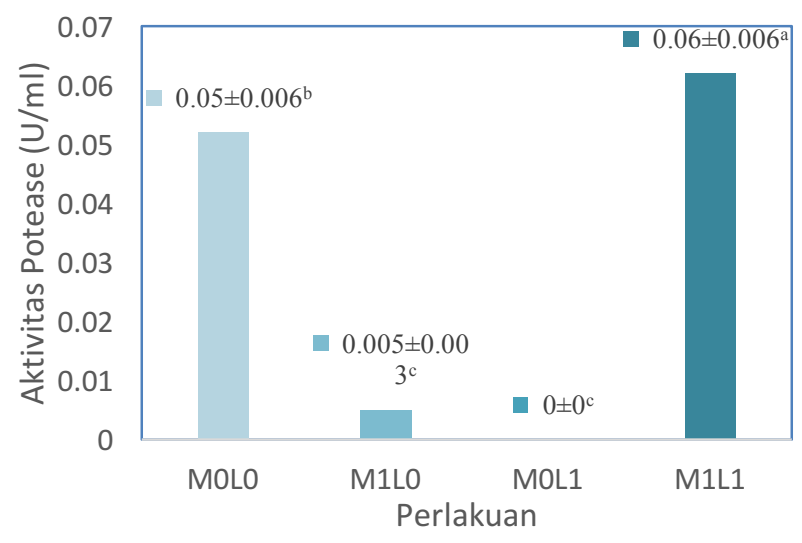

Gambar 4. Aktivitas Enzim Protease Bacillus sp.

Keterangan : $M_{0} L_{0}$ : media kontrol (tanpa induktor Fe dan $Z n$ ), $M_{1} L_{0}$ : media kontrol, dipapar medan magnet (tanpa induktor Fe dan $\mathrm{Zn}$ ), $\mathrm{MoL}_{1}$ : media dengan induktor $\mathrm{FeCl}_{3}$ tanpa dipapar medan magnet, $M_{1} L_{1}$ : media dengan induktor $\mathrm{FeCl}_{3}$ dipapar medan magnet,

Tingginya aktivitas enzim protease pada perlakuan $\mathrm{M}_{1} \mathrm{~L}_{1}$ diduga karena adanya penambahan ion logam $\mathrm{Fe}$ dalam bentuk garam $\mathrm{FeCl}_{3}$ sebanyak $0.01 \%$ yang telah dipapar medan magnet. Menurut Sutresna (2006) ketika Fe dipapar oleh medan magnet, maka Fe akan termagnetisasi searah dengan arah medan magnet karena Fe merupakan golongan logam yang bersifat ferromagnetik sehingga jika ditambahkan dalam media pertumbuhan bekteri, medan magnet akan tetap ada dan dapat mempengaruhi aktivitas metabolisme dari bakteri tersebut. $\mathrm{FeCl}_{3}$ yang telah diberi medan magnet berperan sebagai koinduktor yang mendorong Bacillus sp menghasilkan protease yang lebih tinggi. Pada penelitian Sumardi dkk (2018), paparan medan magnet pada medium yang mengandung Fe sebesar 0,10 U/ml lebih tinggi dibandingkan dengan media yang sama tanpa pemaparan medan magnet yakni sebesar 0,07 $\mathrm{U} \mathrm{ml}$. Karakter enzim juga mengalami perubahan. Perubahan tersebut diduga karena perubahan struktur protein enzim sehingga nilai $\mathrm{Km}$ berubah. Perubahan struktur protein menyebabkan perubahan afinitas enzim terhadap substrat. Afinitas tersebut diandai dengan nilai $\mathrm{Km}$. Pada medium dengan Fe yang dipapar medan magnet mempunyai $\mathrm{Km} \mathrm{5,64}$ sedangkan yang dipapar medan magnet mempunyai Km 10,04. Sedangkan pada penelitian lain yang dilakukan oleh Hernawati dkk. (2014), membuktikan bahwa pemaparan medan magnet dapat mempercepat pertumbuhan Bacillus sp. Hal tersebut diduga karena medan magnet membantu mempercepat penyerapan nutrien sehingga menaikkan produksi enzim selulase dan pertumbuhan Bacillus sp. hingga waktu 18 jam.

\section{Kesimpulan}

Larutan ion logam $\mathrm{Fe}$ 0,01\% dalam media padat menyebabkan indeks proteolitik yang relatif kecil (1,79 untuk 10 jam dan 2,12 untuk 18 jam). Dengan 
Sumardi, Agustrina R., Irawan B., dan I. Selfiana. (2018). Pengaruh Paparan Medan Magnet 0,2 mT pada Ion Logam Fe dan Zn dalam media pertumbuhan terhadap produksi Protease Bacillus sp. Jurnal Ilmu Lingkungan, 16(2), 173-177,doi:10.14710/jil.16.2.173-177

paparan medan magnet menyebabkan kenaikan indeks proteolitik (3,36 untuk 10 jam dan 2,74 untuk 18 jam). Sedangkan pada larutan ion logam $\mathrm{Zn}$ menyebabkan sel Bacillus mati sehingga tidak ada produksi protease. Larutan ion logam Fe 0,01\% dalam

\section{Ucapan Terima Kasih}

Riset penulis dibiayai oleh Hibah Peneletian Pascasarjana Universitas Lampung dengan kontrak No: 963/UN26.21/PP/2016, Tanggal 28 oktober 2016

\section{Daftar Pustaka}

Agustrina R, Handayani T T, dan Sumardi. 2013. Observation of the effect of static magnetic field $0.1 \mathrm{mt}$ on $\checkmark$ amylase activity in legume germination. Proseding 2nd International Conference on Engineering and Technology Development (ICETD) Faculty of Engineering and Faculty of Computer Science

Bacillus Sp. Jurnal Penelitian Pertanian Terapan Vol. 16 (2): 76 - 84 http://www.jptonline.or.id

Bergmeyer dan Grassl, 1983. Methods of Enzymatic Analysis 2. Verlag Chemia. Weinhein.

Durham, D. R., D. B. Stewart, and E. J. Stellwag. 1987. Novel alkaline and heat stable serine proteases from alkalaphilic Bacillus sp. strain GX6638. J. Bacterial., 169(6): 2762- 2768.

field $0.2 \mathrm{mt}$. IOP Conf. Series: Earth and Environmental Science $130 \quad 012046$ doi :10.1088/17551315/130/1/012046

He, S., Y. Feng, H. Ren, and Y. Zhang. 2011. The Impact Of Iron Oxide Magnetic Nanoparticles On The Soil Bacterial Community. School of Biological Science and Medical Engineering. 11: 1408-1417. China.

Hernawati W, Sumardi, Agustrina R, dan Yulianto H. 2016. Pengaruh Pemaparan Medan Magnet Pada Media Mandels Yang Dimodifikasi Terhadap Pertumbuhan Dan Aktivitas Enzim Selulase, ISSN 1410-5020 eISSN Online 2047-1781

Kementerian Lingkungan Hidup. 2014. Peraturan Menteri Lingkungan Hidup No. 5 Tahun 2014 Tentang Baku Mutu Air Limbah.

Kobya, M., E. Sentruk, C. Aydiner and E. Demirbas. 2006. Treatment of potato chips manufacturing waste water by electroagulation. Desalination, 190: 201-211.

Kundu, P., A. Dabsarkar, S. Mukherjee. 2013. Treatment of Slaughter House Wastewater in a sequencing Batch Reactor, Performance evaluation and Biodegradation Kinetics. Hindawi Publishing Corporation, BioMed Research International Article ID134872, II pages.

Lie, Jie. 2015. Study on the effect of magnetic field treatment of newly isolated Paenibacillus sp. Botanical Studies (2015) 56:2

Rumah Potong Hewan Ruminansia dan Unit Penanganan daging (meat cutting plant).

Said, M.I dan J.C. Likadja. 2012. Isolasi dan Identifikasi Bakteri yang Berpotensi Sebagai Penghasil Enzim Protease Pada Industri Penyamakan Kulit PT. Adhi Satria Abadi (ASA), Yogyakarta. JITP Vol. 2 No. 2. UGM

Sari. E.K.N., Susilo. B., danSumarlan.S.IH. 2012. Proses Pengawetan Sari Buah Apel (Mallussylvertris Mill) Secara Non Thermal Berbasis Teknologi Oscillating Magnetic Field (OMF). Jurnal Teknologi Pertanian Vol.13 No.2 (Agustus 2012) 78-87. media cair menghasilkan produksi protease lebih baik $(0,06 \mathrm{U} / \mathrm{ml})$ dibandingkan dengan tanpa pemaparan medan magnet $(0 \mathrm{U} / \mathrm{ml})$.

Soeka Y. S., dan Sulistiani. 2014. Karakterisasi Protease Bacillus Subtilis A1 Inacc B398 yang Diisolasi Dari Terasi Samarinda. Berita Biologi 13(2).

Sudarti, Nurhayati, Eka Ruriani, Vonni Triana Hersa. 2014. Prevalence of Salmonella Typhimurium on Gado-Gado Seasoning by Treatment of Extremely Low Frequency (ELF) Magnetic Field.Artikel-ELF-Salmonella. Jember University

Sumardi, Agustrina R, Ekowati C.N., and Pasaribu Y S. 2018. Characterization of protease from bacillus $\mathrm{sp}$. on medium containing $\mathrm{FeCl} 3$ exposed to magnetic

Sumardi, C. N. Ekowati dan D. Handayani. 2010. Isolasi Bacillus Penghasil Selulase dari Saluran Pencernaan Ayam Kampung. Jurnal Sains Mipa, April 2010, Vol. 16, No.1, Hal:62-68. Universitas Lampung

Sutresna. 2006. Fisika Dasar: Lisrik, magnet, dan termofisika.penerbit ITB. Bandung

Trianie, FA. 2014. Pengaruh fortifikasi besi dan zinc terhadap Total bakteri asam laktat, ph, dan Organoleptik yoghurt susu kambing sinbiotik. Fakultas Kedokteran Universitas Diponegoro Semarang.

Vidyasagar, S.B. Prakash and K. Sreeramulu. 2006. Optimization of culture conditions for the production of haloalkaliphilic thermostable protease from an extremely halophilic archaeon Halogeometricum sp. TSS101 M. The Society for Applied Microbiology, Letters in Applied Microbiology 43: 385-391

Vijayaraghavan, Ponnuswamy dan Samuel Gnana Prakash Vincent. 2013. A simple method for the detection of protease activity on agar plates using bromocresolgreen dye. J Biochem Tech 4(3): 628-630

Yusufa, Mohammad H., Masdiana C. Padaga, Dyah A., dan Octavianie. 2012. Identifikasi dan studi aktivitas protease Bacillus sp asal limbah cair rumah potong ayam tradisional sebagai kandidat penghasil biodeterjen. Universitas Brawijaya.

Zahidah, D. dan M. Shovitri. 2013. Isolasi, Karakterisasi dan Potensi Bakteri Aerob Sebagai Pendegradasi Limbah Organik. Jurnal sains dan seni pomits vol. 2, no.1. 1215 